Article

\title{
Evaluation of the Undrained Shear Strength in Preconsolidated Cohesive Soils Based on the Seismic Dilatometer Test
}

\author{
Paweł Galas $^{1}$, Zbigniew Lechowicz ${ }^{1, * \mathbb{D}}$ and Maria Jolanta Sulewska ${ }^{2}$ (D) \\ 1 Faculty of Civil and Environmental Engineering, Warsaw University of Life Sciences-SGGW, \\ Nowoursynowska 159 St., 02-776 Warsaw, Poland; galaspawel@o2.pl \\ 2 Faculty of Civil and Environmental Engineering, Bialystok University of Technology, Wiejska 45E St., \\ 15-351 Bialystok, Poland; m.sulewska@pb.edu.pl \\ * Correspondence: zbigniew_lechowicz@sggw.pl; Tel.: +48-22-59-35200
}

Received: 20 March 2019; Accepted: 18 April 2019; Published: 22 April 2019

\begin{abstract}
The undrained shear strength in cohesive soils can be evaluated based on measurements obtained from the standard dilatometer test (DMT) using single- and multi-factor empirical relationships. However, the empirical relationships presented in the literature may sometimes show relatively high values of the maximum relative error. The add-on seismic module to the seismic dilatometer test (SDMT) extends parameters measurable in a standard dilatometer test by the shear wave velocity $V_{S}$ as an independent variable. Therefore, a method for evaluating the undrained shear strength in cohesive soils based on data obtained from the seismic dilatometer test is presented in this study. In the method proposed, the two-factor empirical relationship for evaluating the normalized undrained shear strength $\tau_{f u} / \sigma_{v}^{\prime}$ is used based on independent variables: The normalized difference between the corrected second pressure reading and the corrected first pressure reading $\left(p_{1}-p_{0}\right) / \sigma_{v}^{\prime}$ and the normalized shear wave velocity $V_{S} / 100$. The proposed two-factor empirical relationship provides a more reliable evaluation of the undrained shear strength in the tested Pleistocene and Pliocene clays in comparison to the empirical relationships presented in the literature, with a maximum relative error max $R E$ at about $\pm 20 \%$ and the mean relative error $R E$ at about $8 \%$.
\end{abstract}

Keywords: cohesive soils; undrained shear strength; seismic dilatometer test; statistical analysis

\section{Introduction}

In order to determine the geotechnical parameters the cone penetration tests and the standard penetration test (SPT) have wide applications. From in situ tests the cone penetration tests (cone penetration test $\mathrm{CPT}$, cone penetration test with pore pressure measurement $\mathrm{CPTU}$, seismic cone penetration test SCPT) have the widest use for estimating geotechnical parameters over a wide range of materials from very soft soils to weak rock. The flat dilatometer tests (DMT, SDMT) have become popular in many countries for estimating geotechnical parameters in non-cohesive and cohesive soils, however, their application is low in gravels and soft rocks [1,2].

The flat dilatometer was developed by Marchetti [3,4]. The detailed procedure for conducting the standard dilatometer test (DMT) and methodology of its interpretation were presented by Marchetti [5,6] and Marchetti et al. [7]. Comprehensive studies have been performed to improve some of the original correlations proposed by Marchetti. Numerous investigations have been made to expand the application of DMT in geotechnical engineering [8-17]. In most cases, the relationships used to evaluate geotechnical parameters from the dilatometer test such as the corrected first pressure 
reading $p_{o}$ or the corrected second pressure reading $p_{1}$, or index parameters such as the material index $I_{D}$, horizontal stress index $K_{D}$, and dilatometer modulus $E_{D}$, are commonly applied.

Supplementing the instrumentation used to perform the dilatometer test with two geophones in the seismic dilatometer test (SDMT) has expanded possibilities of interpreting the test results $[18,19]$. The use of geophones enabled making measurements of an additional parameter in the form of shear wave velocity $\mathrm{V}_{\mathrm{s}}$. In this way, the SDMT, similarly to the SCPT, provides an additional measurement enabling the seismic assessment of the studied area and a more precise determination of many geotechnical parameters. Although the seismic dilatometer is used just for slightly more than twenty years, there is already extensive literature discussing the use of SDMT in soil characterization [20-25], assessment of geotechnical parameters [26-31], and design of geotechnical structures [32,33]. The shear wave velocity $V_{s}$ with dilatometer measurements have been used so far to evaluate the initial shear modulus $G_{0}[19,26,28]$, decay of the shear modulus $G$ with the shear strain $\gamma[19,29]$, interrelationship between $G_{0}$ and operative modulus [27], detecting the presence of cementation [5], and cyclic resistance ratio CRR [30].

Undrained shear strength $\tau_{f u}$ is the basic parameter in the geotechnical design of different structures [34-47]. Evaluation of this parameter using dilatometer tests is usually based on empirical relationships. In single-factor relationship proposed by Marchetti [3] the horizontal stress index $K_{D}$ is used as the independent variable. Roque et al. [38] proposed an approach for estimating undrained shear strength using the corrected second pressure reading $p_{1}$. A different relationship was proposed by Smith and Houlsby [39], in which undrained shear strength was a function of the corrected first pressure reading $p_{0}$. For normally consolidated marine clays, Iwasaki and Kamei [40] proposed a relationship, in which the dilatometer modulus $E_{D}$ is as independent variable.

A multi-factor relationship was proposed by Rabarijoely [41] to evaluate undrained shear strength $\tau_{f u}$, in which as independent variables were the in situ effective vertical stress $\sigma_{v}^{\prime}$, as well as the net value of the corrected first pressure reading $\left(p_{0}-u_{0}\right)$ and the net value of a corrected second pressure reading $\left(p_{1}-u_{0}\right)$. Galas [42] proposed a multi-factor relationship, in which the normalized net value of the corrected first pressure reading $\left(p_{0}-u_{0}\right) / \sigma_{v}^{\prime}$ and the normalized net value of the corrected second pressure reading $\left(p_{1}-u_{0}\right) / \sigma_{v}^{\prime}$ were used as independent variables.

It should be noted that the regional geotechnical conditions could have substantial influence on the empirical relationships and the values of empirical coefficients [43-48]. It is important to point out, that the shear wave velocity $V_{s}$ as an independent variable was not used so far to evaluate the undrained shear strength from the dilatometer test.

This paper presents the results of seismic dilatometer tests SDMT and laboratory tests of preconsolidated cohesive soils (Pleistocene clays and Pliocene clays). The undrained shear strength in cohesive soils is evaluated based on measurements obtained from the dilatometer test using single- and multi-factor empirical relationships presented in the literature. However, the empirical relationships sometimes show relatively high values of the maximum relative error max $R E$. In this study a method for evaluating the undrained shear strength of preconsolidated cohesive soils using statistical analysis based on data obtained from a seismic dilatometer test is presented. The presented multi-factor empirical relationship predicts the normalized undrained shear strength based on two independent variables: The normalized difference between the corrected second pressure reading and the corrected first pressure reading $\left(p_{1}-p_{o}\right) / \sigma_{v}^{\prime}$ and the normalized shear wave velocity $V_{s} / 100$. The proposed multi-factor empirical relationship provides a more reliable prediction of the undrained shear strength in comparison to the empirical relationships presented in the literature, with a max $R E$ at about $\pm 20 \%$ and the mean relative error $R E$ at about $8 \%$. 


\section{Methods and Materials}

\subsection{Dilatometer Test Procedure}

Standard DMT test procedure involves pushing the blade vertically into the ground with readings at selected test depths. The readings are generally made at every $0.2 \mathrm{~m}$ of depth. The first $A$-reading pressure occurs at membrane "lift-off" and the second B-reading pressure after $1.1 \mathrm{~mm}$ movement $[5-7,49,50]$.

After appropriate corrections described by Marchetti, the values of $A$ and $B$ pressures yield the values of the corrected first pressure reading $p_{o}(0.00 \mathrm{~mm}$ expansion $)$ and the corrected second pressure reading $p_{1}$ [4]. Based on the corrected pressure readings $p_{0}$ and $p_{1}$, as well as in situ hydrostatic pore pressure $u_{0}$ and in situ effective vertical stress $\sigma_{v}^{\prime}$, the following index parameters were proposed by Marchetti [3]:

Material index

$$
I_{D}=\left(p_{1}-p_{o}\right) /\left(p_{o}-u_{o}\right)
$$

Horizontal stress index

$$
K_{D}=\left(p_{o}-u_{o}\right) / \sigma_{v}^{\prime}
$$

Dilatometer modulus

$$
E_{D}=34.7 \cdot\left(p_{1}-p_{o}\right)
$$

The use of a seismic dilatometer SDMT with two geophones enabled making additional measurements of shear wave velocity $V$ s every $0.5 \mathrm{~m}$ of depth (Figure 1 ).

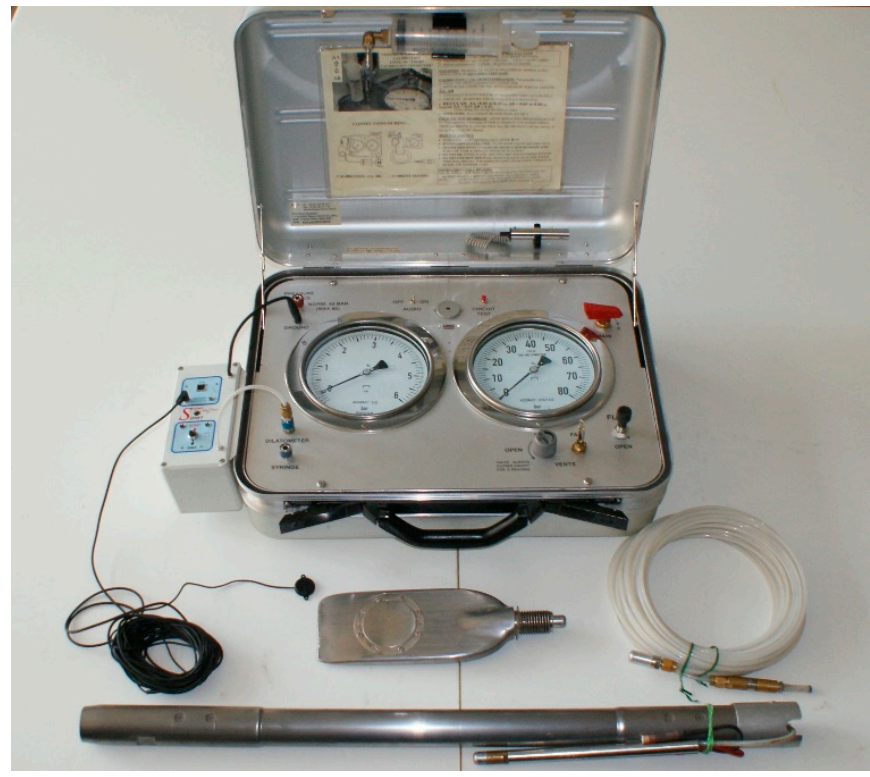

Figure 1. Dilatometer blade, measuring unit and seismic module of the seismic dilatometer test (SDMT).

\subsection{Evaluation of Undrained Shear Strength From the Dilatometer Test}

\subsubsection{Single-Factor Relationships}

Marchetti [3] proposed the following basic correlation between the normalized undrained shear strength and the horizontal stress index $K_{D}$ for cohesive soils (for material index $I_{D}<1.2$ ):

$$
\frac{\tau_{f u}}{\sigma_{v}^{\prime}}=0.22 \cdot\left(0.5 \cdot K_{D}\right)^{1.25}
$$


Analysis of the DMT results presented in the literature [10,43-45,47] indicates that for particular soils, the relationship between the overconsolidation ratio $(O C R)$ and the horizontal stress index $K_{D}$, as well as the normalized undrained shear strength and the horizontal stress index $K_{D}$ differ from that proposed by Marchetti [3] and can be modified as follows:

$$
\frac{\tau_{f u}}{\sigma_{v}^{\prime}}=S \cdot\left(n \cdot K_{D}\right)^{m}
$$

where $S=\left(\tau_{f u} / \sigma_{v}^{\prime}\right)_{n c}$ is the normalized undrained shear strength for normally consolidated soil, and $n$ and $m$ are empirical coefficients. It has long been recognized that normalized undrained shear strength in normally consolidated soil depends on the mode of testing, boundary conditions, strain rate, and other variables $[34,35,37,44]$. The different values of the $S, n$, and $m$ parameters are shown in Table 1.

Table 1. Empirical coefficients in single- and multi-factor relationships to evaluate undrained shear strength $\tau_{f u}$ from the dilatometer test.

\begin{tabular}{|c|c|c|c|}
\hline Author & Equation & $\begin{array}{l}\text { Independent } \\
\text { Variable }\end{array}$ & Empirical Coefficients \\
\hline \multicolumn{4}{|c|}{ Single-Factor Empirical Relationships } \\
\hline Marchetti [3] & (4) & $K_{D}$ & $\begin{array}{c}\text { Marchetti [3] } \\
\text { cohesive soils } \\
\text { for } I_{D}<1.2 \\
S=0.22, n=0.5, m=1.25\end{array}$ \\
\hline Modified Marchetti & (5) & $K_{D}$ & $\begin{array}{c}\text { Kamei and Iwasaki [44] } \\
\text { marine clays } \\
S=0.35, n=0.47, m=1.14\end{array}$ \\
\hline Roque et al. [38] & (6) & $\left(p_{1}-\sigma_{h o}\right)$ & $\begin{array}{c}\text { Roque et al. [38] } \\
\text { clays } N_{C}=5-9 \\
\text { Galas [42] } \\
\text { Pleistocene and Pliocene clays } \\
N_{C}=9.9\end{array}$ \\
\hline Smith and Houlsby [39] & (7) & $\left(p_{0}-\sigma_{h o}\right)$ & $\begin{array}{c}\text { Smith and Houlsby [39] } \\
\text { clays } N_{D}=4-7 \\
\text { Galas [42] } \\
\text { Pleistocene and Pliocene clays } \\
N_{D}=4.9\end{array}$ \\
\hline \multicolumn{4}{|c|}{ Multi-Factor Empirical Relationships } \\
\hline Rabarijoely [41] & (9) & $\begin{array}{c}\sigma_{v}^{\prime} \\
\left(p_{o}-\sigma_{h o}\right) \\
\left(p_{1}-\sigma_{h o}\right)\end{array}$ & $\begin{array}{c}\text { Lechowicz et al. [51] } \\
\text { Pleistocene and Pliocene clays } \\
\alpha_{\mathrm{o}}=0.18, \alpha_{1}=0.14, \alpha_{2}=0.20, \alpha_{3}=0.15\end{array}$ \\
\hline Galas [42] & $(10)$ & $\begin{array}{c}\left(p_{0}-\sigma_{h o}\right) / \sigma_{v}^{\prime} \\
\left(p_{1}-\sigma_{h o}\right) / \sigma_{v}^{\prime}\end{array}$ & $\begin{array}{c}\text { Galas [42] } \\
\text { Pleistocene and Pliocene clays } \\
a_{o}=0.164, a_{1}=0.345, a_{2}=0.544\end{array}$ \\
\hline
\end{tabular}

Roque et al. [38] proposed a relationship for estimating the undrained shear strength based on the corrected second pressure reading $p_{1}$ :

$$
\tau_{f u}=\left(p_{1}-\sigma_{h o}\right) / N_{C}
$$

where $\sigma_{h o}$ is the in situ horizontal total stress, and $N_{C}$ is the dilatometer factor for clays that varies from about 5 to 9 . The research carried out by Roque et al. [38] and Galas [42] indicates the values of $N_{C}$ factor as shown in Table 1.

A different relationship has been proposed by Smith and Houlsby [39], in which the undrained shear strength was a function of the corrected first pressure reading $p_{0}$ :

$$
\tau_{f u}=\left(p_{o}-\sigma_{h o}\right) / N_{D}
$$

where $N_{D}$ is the dilatometer bearing capacity factor, whose values are shown in Table 1. 
For normally consolidated marine clays Iwasaki and Kamei [40] proposed a relationship, in which the dilatometer modulus $E_{D}$ is the independent variable:

$$
\tau_{f u}=0.018 \cdot E_{D}
$$

\subsubsection{Multi-Factor Relationships}

A multi-factor relationship was proposed by Rabarijoely [41] to evaluate the undrained shear strength $\tau_{f u}$ of organic soils (organic mud, gyttja, and peat):

$$
\tau_{f u}=\alpha_{o} \cdot \sigma_{v}^{\prime \alpha_{1}} \cdot\left(p_{o}-u_{o}\right)^{\alpha_{2}} \cdot\left(p_{1}-u_{o}\right)^{\alpha_{3}}
$$

where $\alpha_{0}, \alpha_{1}, \alpha_{2}, \alpha_{3}$ are the empirical coefficients. In this relationship, three factors are taken into account: The in situ effective vertical stress $\sigma_{v}^{\prime}$, the net value of the corrected first pressure reading $\left(p_{0}-u_{0}\right)$ and the net value of the corrected second pressure reading $\left(p_{1}-u_{0}\right)$. The net values of the corrected first and second pressure readings were obtained by subtracting the in situ hydrostatic pore pressure $u_{o}$ from $p_{o}$ and $p_{1}$. The empirical coefficients to Equation (9) for Pleistocene clays and Pliocene clays evaluated by Lechowicz et al. [51] are shown in Table 1.

A two-factor relationship was proposed by Galas [42] to evaluate the normalized undrained shear strength $\tau_{f u} / \sigma_{v}^{\prime}$ of preconsolidated cohesive soils:

$$
\frac{\tau_{f u}}{\sigma_{v}^{\prime}}=a_{0} \cdot\left(\frac{p_{0}-u_{0}}{\sigma_{v}^{\prime}}\right)^{a_{1}} \cdot\left(\frac{p_{1}-u_{0}}{\sigma_{v}^{\prime}}\right)^{a_{2}}
$$

where $a_{0}, a_{1}, a_{2}$ are the empirical coefficients. In this relationship, two factors are taken into account: The net value of the corrected first pressure reading normalized by in situ effective vertical stress $\sigma_{v}^{\prime}$ and the net value of the corrected second pressure reading normalized by in situ effective vertical stress $\sigma_{v}^{\prime}$. The empirical coefficients to Equation (10) for Pleistocene clays and Pliocene clays evaluated by Galas [42] are shown in Table 1.

\subsection{Characteristics of the Tested Cohesive Soils}

Field tests coupled with laboratory tests were performed on three test sites located in Warsaw, Poland (Figure 2). The tested cohesive soils are Pleistocene moraine and lacustrine clays and Pliocene clays.

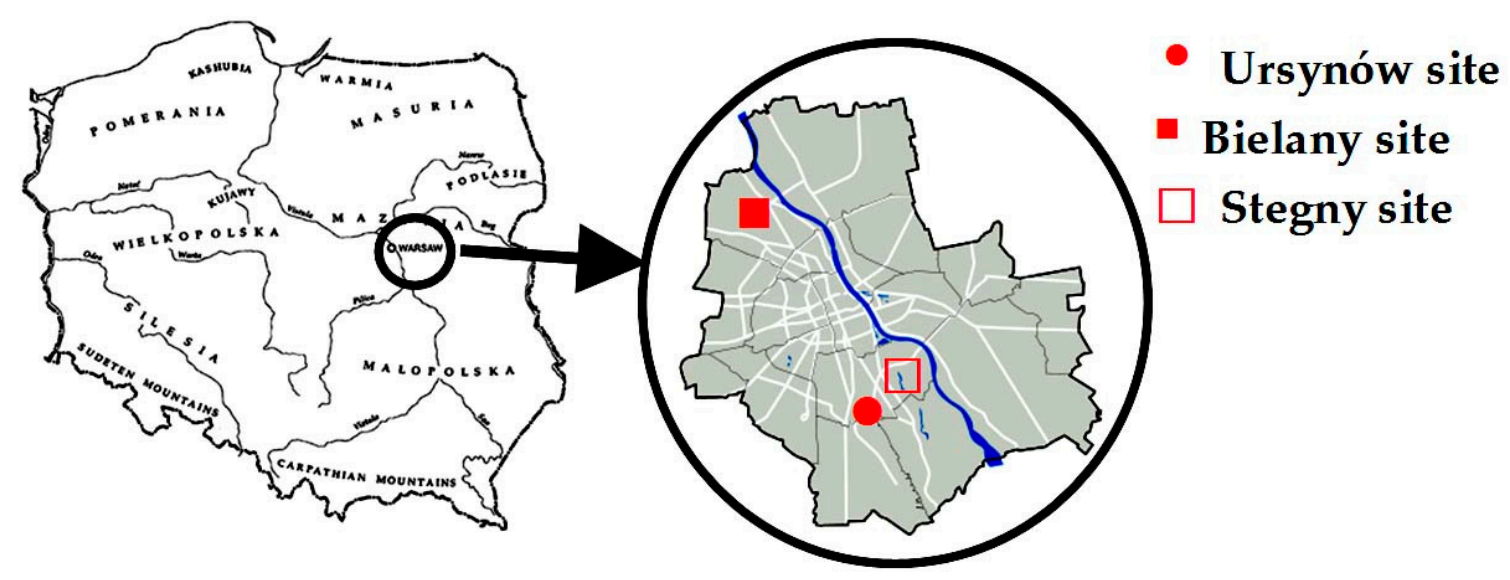

Figure 2. Location of test sites in Warsaw, Poland.

\subsubsection{Ursynów Site}

The Ursynów site is located on the Warsaw University of Life Sciences-SGGW campus in the southern part of Warsaw. Three locations were selected here: The Conference Auditorium, 
Building No. 37, and Building No. 34. The tested subsoil consists of anthropogenic fill with thickness 3.5-4.0 $\mathrm{m}$ below Pleistocene moraine deposits of the Riss Glaciation classified as stiff brown moraine clays of the Warta Glaciation with thickness from $2 \mathrm{~m}$ to $4 \mathrm{~m}$ and grey moraine clays of the Odra Glaciation with a thickness of $2.5-3.0 \mathrm{~m}$.

The cohesive soils are underlain by Quaternary sands of the Mazovian Interglacial whose top lies at $9.5 \mathrm{~m}$ to $10.0 \mathrm{~m}$ below ground level. There is one aquifer on the Ursynów site; a free groundwater table is found in sands at a depth of $10 \mathrm{~m}$ to $12 \mathrm{~m}$ below ground level.

Glacial moraine deposits of the Warta and Odra Glaciations are classified as low plasticity clays. Grain size distribution of the tested soils (Figure 3) shows that according to EN ISO 14688-1 and 2 Standards [52,53], the glacial moraine clays are classified as silty sandy clays (sasiCl) and clayey sands (clSa). The index properties of the tested soils for nine undisturbed soil samples (No. 1-9) are shown in Table 2. The glacial moraine clays are preconsolidated with an overconsolidation ratio OCR determined from SDMT decreasing with depth from 20 to 12 for brown moraine clays of the Warta Glaciation and from 15 to 8 for grey moraine clays of the Odra Glaciation.

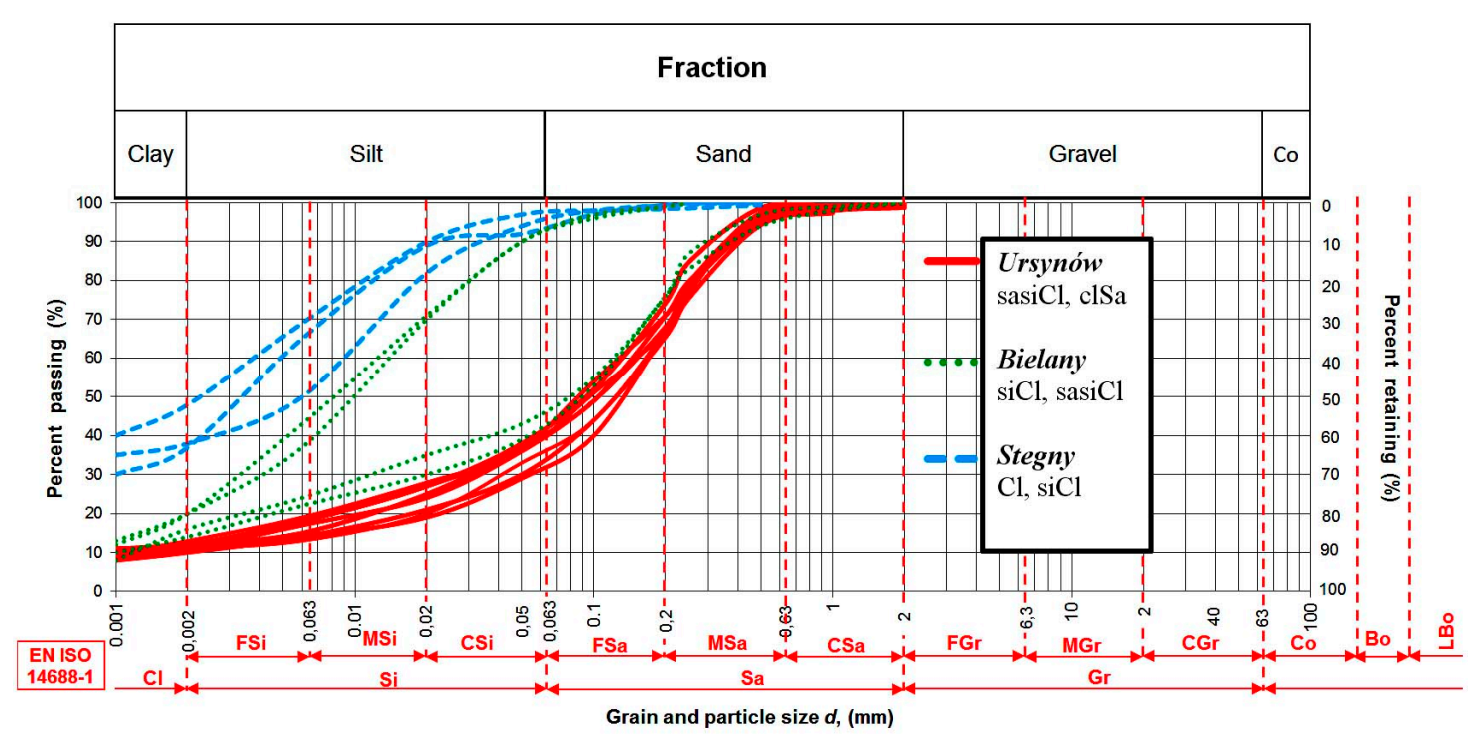

Figure 3. Grain size distribution of the tested cohesive soils. 
Table 2. Index properties of the tested cohesive soils.

\begin{tabular}{|c|c|c|c|c|c|c|c|c|c|c|c|c|}
\hline \multirow[t]{2}{*}{ No. } & \multirow{2}{*}{$\begin{array}{c}\text { Soil Type } \\
\text { [53] }\end{array}$} & \multirow{2}{*}{$\begin{array}{l}\text { Depth } \\
\text { (m) }\end{array}$} & \multirow[t]{2}{*}{$\begin{array}{l}w_{n} \\
(\%)\end{array}$} & \multirow[t]{2}{*}{$\begin{array}{l}w_{L} \\
(\%)\end{array}$} & \multirow[t]{2}{*}{$\begin{array}{l}w_{P} \\
(\%)\end{array}$} & \multirow[t]{2}{*}{$\begin{array}{c}I_{P} \\
(\%)\end{array}$} & \multirow{2}{*}{$\begin{array}{l}I_{C} \\
(-)\end{array}$} & \multicolumn{4}{|c|}{$\begin{array}{c}\text { Fraction [52] } \\
(\%)\end{array}$} & \multirow[t]{2}{*}{$\begin{array}{c}\text { Activity } \\
\text { A (-) }\end{array}$} \\
\hline & & & & & & & & Gr & Sa & $\mathrm{Si}$ & $\mathrm{Cl}$ & \\
\hline \multicolumn{13}{|c|}{ Ursynów site-Auditorium } \\
\hline 1 & $\mathrm{clSa} / \mathrm{sasiCl}$ & $5.0-5.3$ & 10.3 & 25.2 & 12.8 & 12.4 & 1.20 & 1 & 59 & 27 & 13 & 0.95 \\
\hline 2 & clSa & $5.3-5.7$ & 8.6 & 24.1 & 11.9 & 12.2 & 1.27 & 1 & 63 & 25 & 11 & 1.11 \\
\hline 3 & $\mathrm{clSa}$ & $7.0-7.4$ & 10.4 & 24.9 & 11.9 & 13.0 & 1.11 & 0 & 61 & 28 & 11 & 1.18 \\
\hline \multicolumn{13}{|c|}{ Ursynów site-Building No. 37} \\
\hline 4 & $\mathrm{clSa}$ & $6.5-6.9$ & 9.0 & 25.1 & 11.7 & 13.4 & 1.20 & 1 & 68 & 20 & 11 & 1.22 \\
\hline 5 & sasiCl & $7.0-7.4$ & 10.4 & 24.6 & 11.9 & 12.7 & 1.12 & 1 & 58 & 30 & 11 & 1.15 \\
\hline 6 & sasiCl & $8.5-8.9$ & 9.9 & 26.5 & 12.4 & 14.1 & 1.18 & 2 & 58 & 29 & 11 & 1.28 \\
\hline \multicolumn{13}{|c|}{ Ursynów site-Building No. 34} \\
\hline 7 & clSa & $6.5-6.9$ & 10.3 & 24.9 & 12.9 & 12.0 & 1.21 & 1 & 66 & 23 & 10 & 1.20 \\
\hline 8 & $\mathrm{clSa} / \mathrm{sasiCl}$ & $7.0-7.4$ & 10.5 & 23.1 & 12.0 & 11.1 & 1.13 & 1 & 60 & 28 & 11 & 1.01 \\
\hline 9 & sasiCl & $8.0-8.4$ & 9.4 & 26.6 & 13.1 & 13.5 & 1.27 & 1 & 59 & 28 & 12 & 1.12 \\
\hline \multicolumn{13}{|c|}{ Bielany site } \\
\hline 10 & sasiCl & $15.0-15.4$ & 410.4 & 30.9 & 13.1 & 17.8 & 1.15 & 1 & 52 & 31 & 16 & 1.11 \\
\hline 11 & $\mathrm{siCl}$ & $7.1-7.6$ & 19.2 & 38.0 & 18.8 & 19.2 & 0.98 & 0 & 7 & 73 & 20 & 0.96 \\
\hline 12 & $\mathrm{siCl}$ & $8.5-8.9$ & 21.1 & 34.6 & 17.5 & 17.1 & 0.79 & 0 & 7 & 73 & 20 & 0.86 \\
\hline 13 & sasiCl & $12.0-12.5$ & 511.4 & 27.7 & 12.3 & 15.4 & 1.05 & 1 & 57 & 29 & 14 & 1.10 \\
\hline \multicolumn{13}{|c|}{ Stegny site } \\
\hline 14 & $\mathrm{Cl}$ & $6.0-6.4$ & 26.0 & 78.4 & 25.9 & 52.5 & 1.00 & 0 & 2 & 50 & 48 & 1.09 \\
\hline 15 & $\mathrm{Cl} / \mathrm{siCl}$ & $9.0-9.4$ & 28.5 & 88.1 & 31.2 & 56.9 & 1.05 & 0 & 6 & 57 & 37 & 1.54 \\
\hline 16 & $\mathrm{Cl} / \mathrm{siCl}$ & $12.0-12.4$ & 419.8 & 67.6 & 25.5 & 42.1 & 1.13 & 0 & 3 & 59 & 38 & 1.11 \\
\hline
\end{tabular}

\subsubsection{Bielany Site}

The Bielany site is located in the northern part of Warsaw. The cohesive soils studied are Pleistocene moraine and lacustrine deposits of the Warta Glaciation with a thickness of about 10-12 $\mathrm{m}$ and the top occurring at $5.5 \mathrm{~m}$ below ground level. The groundwater table was found at the depth of $5.4 \mathrm{~m}$, or in the form of sifting in sandy interbeddings of cohesive soils. The main aquifer is drilled at the depth of 15.5-17.5 m; it is tight and stabilizes at the depth of about $5 \mathrm{~m}$ below ground level.

Moraine and lacustrine deposits of the Warta Glaciation are low plasticity clays. Grain size distribution of the tested soils (Figure 3) shows that according to EN ISO 14688-1 and 2 Standards [52,53], the cohesive soils are classified as silty sandy clays $(\mathrm{sasiCl})$ and silty clays $(\mathrm{siCl})$. The index properties of the tested soils for four undisturbed soil samples (No. 10-13) are shown in Table 2. The moraine and lacustrine clays are preconsolidated with overconsolidation ratio, $O C R$, increasing with depth from 3 to 7 .

\subsubsection{Stegny Site}

The Stegny test site is located in the Vistula valley, on a floodplain terrace in the southern part of Warsaw. The cohesive soils tested occur in a glaciotectonically disturbed area and represent stiff Pliocene clays covered with fine and medium sands from the Würm-Vistula Glaciation period, with a thickness of $4.0-5.0 \mathrm{~m}$. Pliocene clays are classified as high plasticity clays. The groundwater table was found at the depth of $3 \mathrm{~m}$. Grain size distribution of the tested soils (Figure 3) shows that according to EN ISO 14688-1 and 2 Standards [52,53], the cohesive soils are classified as silty clays ( $\mathrm{siCl})$ and clays $(\mathrm{Cl})$. The index properties of the tested soils for three undisturbed soil samples (No. 14-16) are shown in Table 2. The glacitectonically disturbed Pliocene clays are preconsolidated with the overconsolidation ratio, $O C R$, increasing with depth from 5 to 8 . 


\section{Results}

\subsection{Results of Seismic Dilatometer Tests}

Field investigations on test sites included seismic dilatometer tests and drillings with collecting of undisturbed soil samples by a Shelby sampler with an inner diameter of $89 \mathrm{~mm}$. As part of the research work, 16 seismic dilatometer tests were made up to a depth of 9.5-16.0 m below ground level. The tests were carried out in nodes consisting of three to four SDMT, located in the vicinity of the borehole. The exceptions included studies carried out at the Bielany site, where the two drillings were completed with two SDMT. The seismic dilatometer test was performed in accordance with Marchetti's guidelines [7,8,19]. In order to generate the shear wave, a steel beam with a hammer construction that allows the hammer head to be easily hit against the beam's forehead was used. A hammer with a weight of approx. $15 \mathrm{~kg}$ and a beam with dimensions of $0.2 \mathrm{~m} \times 0.7 \mathrm{~m} \times 0.1 \mathrm{~m}$ were used. The instrument used to generate the waves in a ground was pressed by means of the probe's foot (Figure 4).

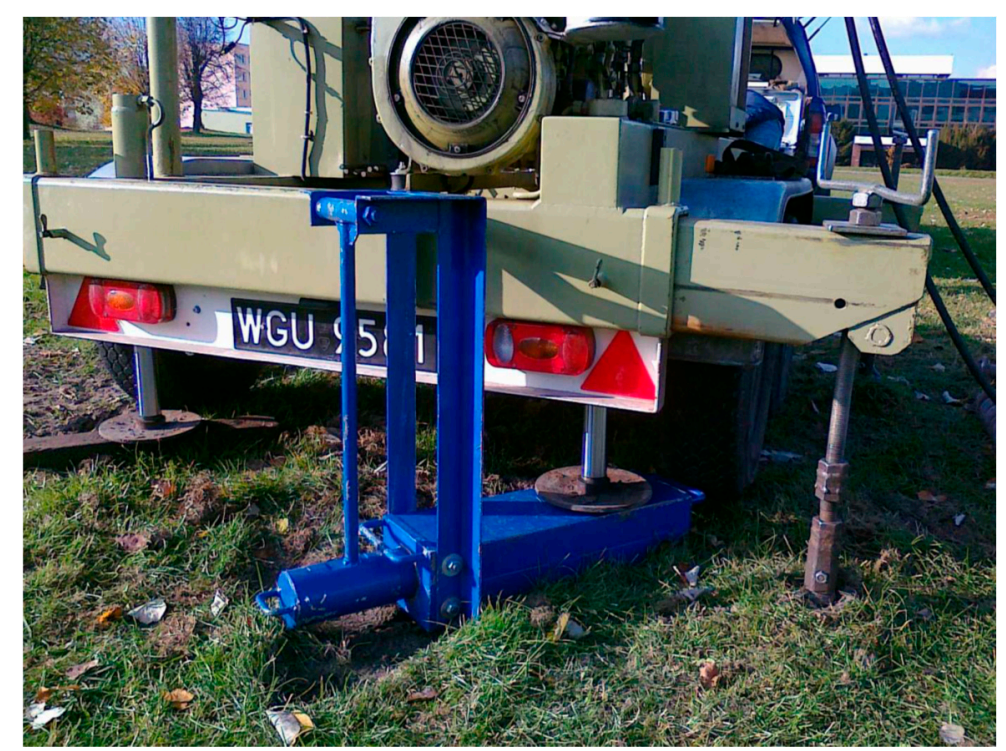

Figure 4. Steel beam with a hammer used to generate shear waves in SDMT.

SDMT data profiles including the corrected pressure readings $p_{o}$ and $p_{1}$, shear wave velocity $V_{s}$ as well as the index parameters $I_{D}, K_{D}$, and $E_{D}$ from dilatometer tests obtained at the Ursynów, Bielany and Stegny sites, respectively, are presented in Figures 5 and 6. The cohesive soils from the Ursynów site showed that the values of the index parameters $K_{D}$ and $E_{D}$ decreased with depth. A greater variation of $K_{D}$ and $E_{D}$ values was obtained in brown moraine clays of the Warta Glaciation than in grey moraine clays of the Odra Glaciation. In the brown moraine clays of the Warta Glaciation the presence of cementation was detected. The index parameters $K_{D}$ and $E_{D}$ were increasing with depth in the moraine and lacustrine deposits of Warta Glaciation from the Bielany site and Pliocene clays from the Stegny site. The mean values, standard deviations and coefficients of variation of these readings and indexes are presented in Table 3. The average coefficients of variation for $V_{s}, I_{D}, K_{D}$, and $E_{D}$ were $0.13,0.43,0.20$, and 0.41 , respectively. The dilatometer modulus $E_{D}$ showed quite a high coefficient of variation. As an independent variable the shear wave velocity $V_{s}$ showed quite a small coefficient of variation. 

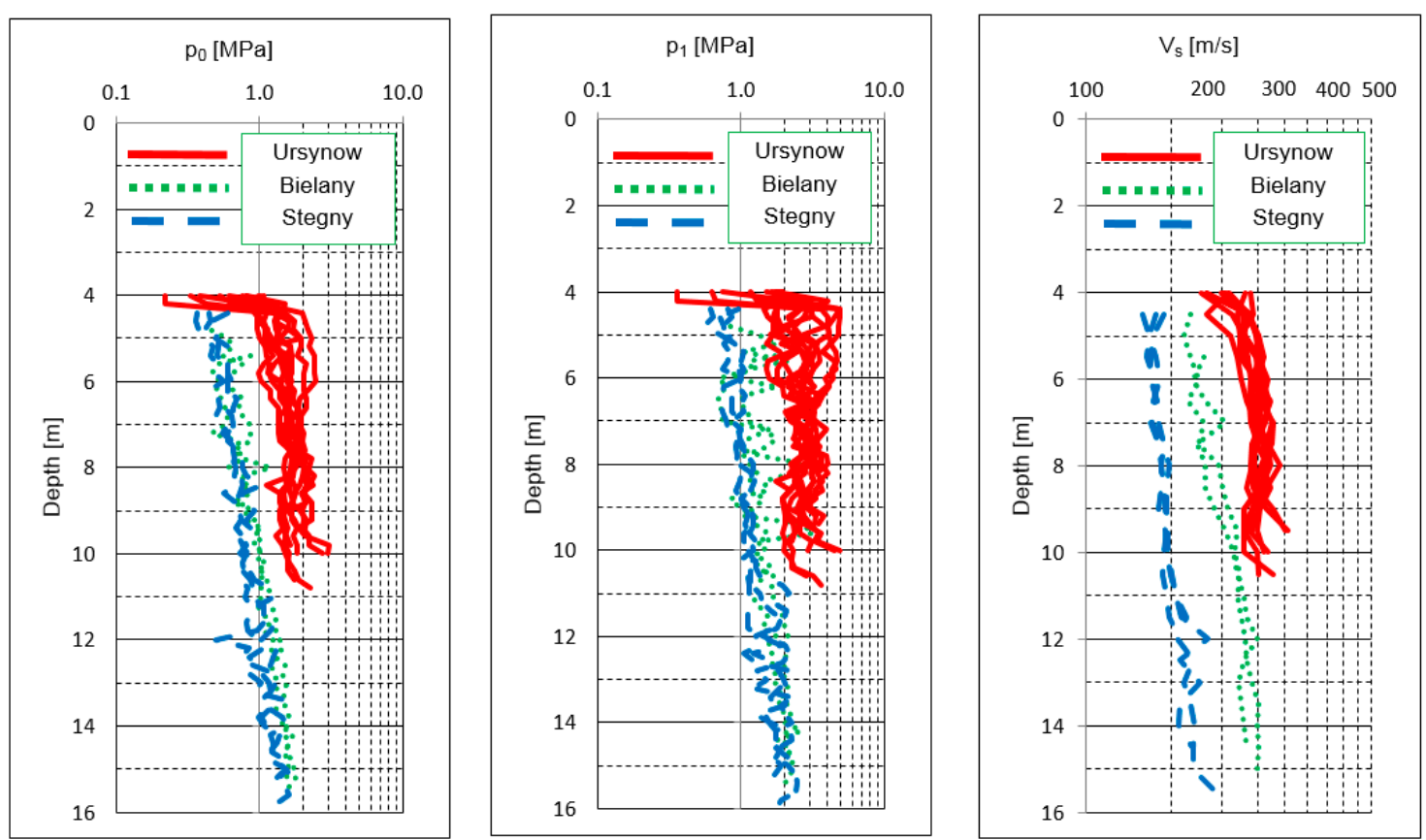

Figure 5. Profiles of the corrected pressure readings $p_{o}$ and $p_{1}$, and shear wave velocity $V_{S}$ from seismic dilatometer tests obtained at the Ursynów, Bielany, and Stegny sites.
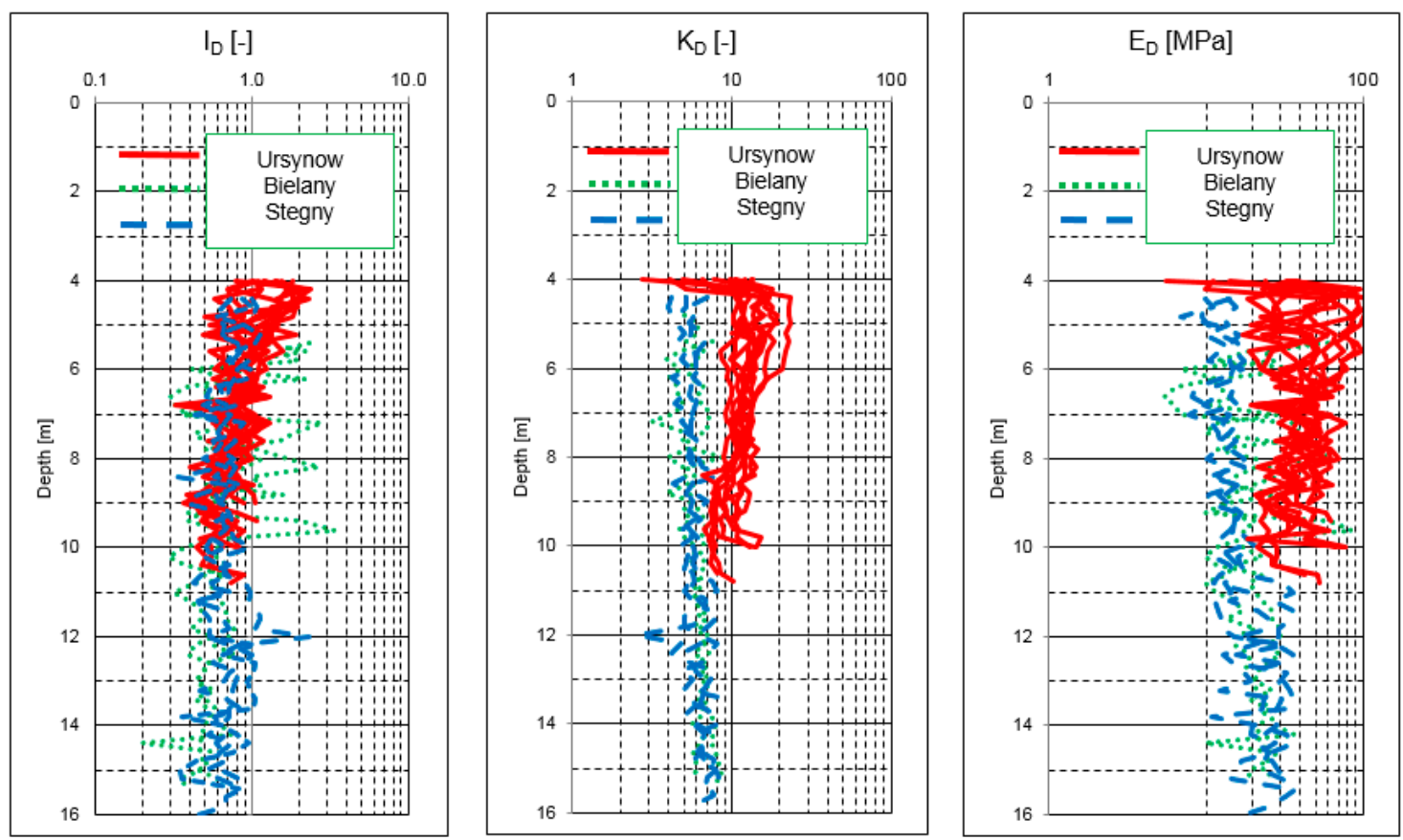

Figure 6. Profiles of the index parameters $I_{D}, K_{D}$, and $E_{D}$ from seismic dilatometer tests obtained at the Ursynów, Bielany, and Stegny sites. 
Table 3. Mean value, standard deviation, and coefficient of variation of: The corrected first pressure reading $p_{o}$ or the corrected second pressure reading $p_{1}$, shear wave velocity $V_{s}$, material index $I_{D}$, horizontal stress index $K_{D}$, and dilatometer modulus $E_{D}$.

\begin{tabular}{|c|c|c|c|c|c|c|c|}
\hline Site & Values & $\begin{array}{c}p_{o} \\
\text { (MPa) }\end{array}$ & $\begin{array}{c}p_{1} \\
(\mathrm{MPa})\end{array}$ & $\begin{array}{c}V_{s} \\
(\mathrm{~m} / \mathrm{s})\end{array}$ & $\begin{array}{l}I_{D} \\
(-)\end{array}$ & $\begin{array}{c}K_{D} \\
(-)\end{array}$ & $\begin{array}{c}E_{D} \\
(\mathrm{MPa})\end{array}$ \\
\hline Ursynów & Mean value & 1.363 & 2.569 & 395 & 0.93 & 11.1 & 42 \\
\hline \multirow[t]{2}{*}{ Auditorium } & Standard Deviation & 0.263 & 0.509 & 47.2 & 0.38 & 2.64 & 14.0 \\
\hline & Coefficient of Variation & 0.19 & 0.20 & 0.12 & 0.41 & 0.24 & 0.33 \\
\hline Ursynów & Mean value & 1.617 & 3.160 & 377 & 0.99 & 12.9 & 54 \\
\hline Building & Standard Deviation & 0.420 & 0.924 & 40.5 & 0.46 & 4.04 & 23.7 \\
\hline No. 37 & Coefficient of Variation & 0.26 & 0.29 & 0.11 & 0.46 & 0.31 & 0.44 \\
\hline Ursynów & Mean value & 1.370 & 2.503 & 397 & 0.84 & 11.3 & 39 \\
\hline Building & Standard Deviation & 0.397 & 0.716 & 41.9 & 0.21 & 1.41 & 13.2 \\
\hline No. 34 & Coefficient of Variation & 0.29 & 0.29 & 0.10 & 0.24 & 0.12 & 0.33 \\
\hline \multirow[t]{3}{*}{ Bielany } & Mean value & 0.972 & 1.610 & 320 & 0.78 & 6.1 & 22 \\
\hline & Standard Deviation & 0.343 & 0.509 & 57.0 & 0.62 & 1.04 & 12.8 \\
\hline & Coefficient of Variation & 0.35 & 0.32 & 0.19 & 0.78 & 0.17 & 0.58 \\
\hline \multirow[t]{3}{*}{ Stegny } & Mean value & 0.810 & 1.337 & 196 & 0.71 & 5.9 & 18 \\
\hline & Standard Deviation & 0.286 & 0.473 & 23.9 & 0.19 & 0.96 & 7.2 \\
\hline & Coefficient of Variation & 0.36 & 0.36 & 0.12 & 0.28 & 0.16 & 0.38 \\
\hline
\end{tabular}

\subsection{Results of Triaxial Tests}

The undrained shear strength $\tau_{f u}$ in cohesive soils from the Ursynów, Bielany, and Stegny sites was determined in CIU triaxial tests on isotropically consolidated samples with shearing in undrained conditions. The CIU triaxial tests were performed in four consecutive stages: Flushing, saturation, consolidation, and shearing in undrained conditions. Saturation of soil samples was performed using the back pressure method. Figure 7 presents the characteristics of the deviator stress $q$ depending on the vertical strain $\varepsilon_{1}$ from CIU triaxial tests for the tested cohesive soils. Based on the deviator stress at failure $q_{f}$ the undrained shear strength was determined as $\tau_{f u}=q_{f} / 2$ which is shown in Table 4 and was used in statistical analysis.

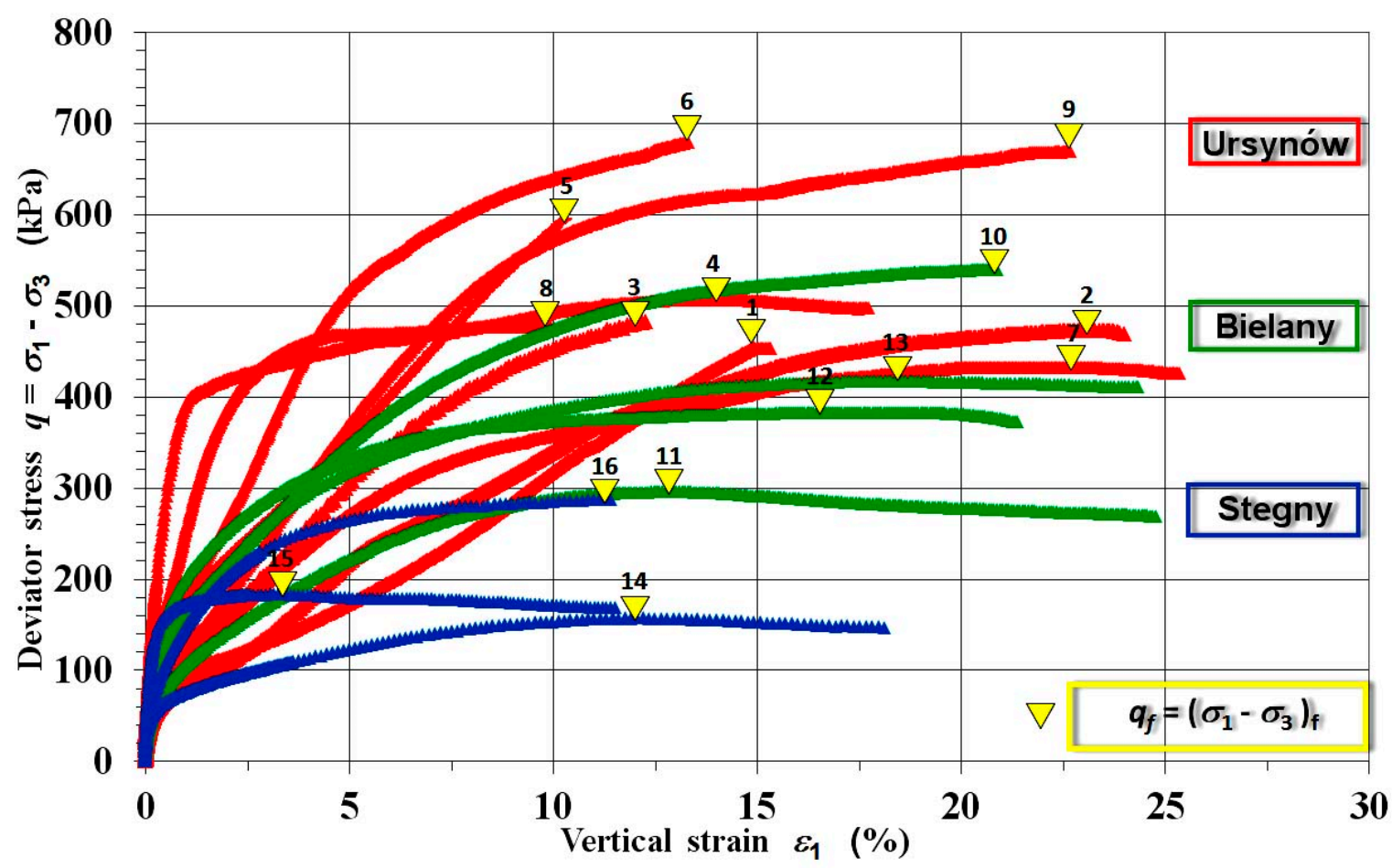

Figure 7. Characteristics of the deviator stress $q$ depending on the vertical strain $\varepsilon_{1}$ from CIU triaxial tests for sixteen tested cohesive soils. 
Table 4. Input and output values for the statistical analysis.

\begin{tabular}{|c|c|c|c|c|c|c|c|c|c|c|c|c|c|c|}
\hline Site & $\begin{array}{l}\text { Soil } \\
\text { Type }\end{array}$ & $\begin{array}{c}\sigma_{v}^{\prime} \\
\text { (MPa) }\end{array}$ & $\begin{array}{c}u_{o} \\
\text { (MPa) }\end{array}$ & $\begin{array}{c}p_{o} \\
\text { (MPa) }\end{array}$ & $\begin{array}{c}\left(p_{o}-u_{o}\right) \\
(\mathrm{MPa})\end{array}$ & $\begin{array}{c}\left(p_{o}-u_{o}\right) / \sigma_{v}^{\prime} \\
(-) \\
X_{1}\end{array}$ & $\begin{array}{c}p_{1} \\
\text { (MPa) }\end{array}$ & $\begin{array}{c}\left(p_{1}-u_{o}\right) \\
(\mathrm{MPa})\end{array}$ & $\begin{array}{c}\left(p_{1}-u_{o}\right) / \sigma_{v}^{\prime} \\
(-) \\
X_{2}\end{array}$ & $\begin{array}{c}\left(p_{1}-p_{o}\right) / \sigma_{v}^{\prime} \\
(-) \\
X_{3}\end{array}$ & $\begin{array}{c}V_{s} \\
(\mathrm{~m} / \mathrm{s})\end{array}$ & $\begin{array}{c}V_{s} / 100 \\
(-) \\
X_{4}\end{array}$ & $\begin{array}{l}\tau_{f u}{ }^{*} \\
\text { (MPa) }\end{array}$ & $\begin{array}{c}\tau_{f u} / \sigma_{v}^{\prime}{ }^{*} \\
(-) \\
Y\end{array}$ \\
\hline \multirow{3}{*}{ Auditorium } & $\mathrm{clSa} / \mathrm{sasiCl}$ & 0.094 & 0.0 & 1.286 & 1.286 & 13.739 & 2.544 & 2.544 & 27.179 & 13.440 & 388 & 3.880 & 0.223 & 2.382 \\
\hline & clSa & 0.102 & 0.0 & 1.399 & 1.399 & 13.743 & 2.802 & 2.802 & 27.525 & 13.782 & 407 & 4.070 & 0.237 & 2.323 \\
\hline & clSa & 0.135 & 0.0 & 1.545 & 1.545 & 11.461 & 2.999 & 2.999 & 22.248 & 10.786 & 424 & 4.240 & 0.240 & 1.780 \\
\hline Ursynów & clSa & 0.124 & 0.0 & 1.662 & 1.662 & 13.361 & 3.074 & 3.074 & 24.707 & 11.346 & 384 & 3.840 & 0.254 & 2.038 \\
\hline Building & sasiCl & 0.137 & 0.0 & 1.583 & 1.583 & 11.580 & 2.829 & 2.829 & 20.695 & 9.115 & 390 & 3.900 & 0.298 & 2.176 \\
\hline No. 37 & sasiCl & 0.170 & 0.0 & 1.631 & 1.631 & 9.594 & 2.604 & 2.604 & 15.318 & 5.724 & 398 & 3.980 & 0.340 & 1.997 \\
\hline Ursynów & clSa & 0.120 & 0.0 & 1.322 & 1.322 & 11.017 & 2.501 & 2.501 & 20.842 & 9.825 & 421 & 4.210 & 0.216 & 1.800 \\
\hline Building & $\mathrm{clSa} / \mathrm{sasiCl}$ & 0.134 & 0.0 & 1.409 & 1.409 & 10.546 & 2.686 & 2.686 & 20.105 & 9.558 & 420 & 4.200 & 0.239 & 1.789 \\
\hline No. 34 & sasiCl & 0.155 & 0.0 & 1.945 & 1.945 & 12.548 & 3.592 & 3.592 & 23.174 & 10.626 & 395 & 3.950 & 0.335 & 2.158 \\
\hline \multirow{4}{*}{ Bielany } & sasiCl & 0.185 & 0.097 & 1.610 & 1.513 & 8.1960 & 2.267 & 2.170 & 11.755 & 3.559 & 398 & 3.980 & 0.270 & 1.463 \\
\hline & $\mathrm{siCl}$ & 0.122 & 0.020 & 0.546 & 0.526 & 4.301 & 1.166 & 1.146 & 9.370 & 5.070 & 247 & 2.470 & 0.148 & 1.209 \\
\hline & $\mathrm{siCl}$ & 0.143 & 0.034 & 0.746 & 0.712 & 4.989 & 1.350 & 1.316 & 9.222 & 4.233 & 283 & 2.830 & 0.192 & 1.342 \\
\hline & sasiCl & 0.189 & 0.068 & 1.267 & 1.199 & 6.341 & 2.075 & 2.007 & 10.613 & 4.273 & 277 & 2.773 & 0.209 & 1.103 \\
\hline \multirow[t]{3}{*}{ Stegny } & $\mathrm{Cl}$ & 0.092 & 0.020 & 0.536 & 0.516 & 5.609 & 0.930 & 0.910 & 9.891 & 4.283 & 175 & 1.750 & 0.079 & 0.853 \\
\hline & $\mathrm{Cl} / \mathrm{siCl}$ & 0.117 & 0.050 & 0.724 & 0.674 & 5.761 & 1.147 & 1.097 & 9.381 & 3.615 & 188 & 1.880 & 0.094 & 0.803 \\
\hline & $\mathrm{Cl} / \mathrm{siCl}$ & 0.142 & 0.080 & 0.873 & 0.793 & 5.585 & 1.528 & 1.448 & 10.197 & 4.613 & 229 & 2.290 & 0.144 & 1.011 \\
\hline
\end{tabular}

Notes: * CIU TT-Triaxial Test on sample consolidated isotropically with shearing in undrained conditions. 


\section{Evaluation of the Undrained Shear Strength Based on Empirical Relationships}

The variables from seismic dilatometer tests used in the evaluation of the undrained shear strength $\tau_{f u}$ are presented in Table 4.

In order to compare the undrained shear strength evaluated on the basis of empirical relationships with undrained shear strength from CIU triaxial tests obtained for a given depth, the measurements from seismic dilatometer tests were subjected to the averaging procedure. The applied procedure consisted of calculating the mean value of pressures $p_{o}$ and $p_{1}$, shear wave velocity $V_{s}$, and index parameter $K_{D}$. The mean value for each selected depth came from three to four dilatometer tests (Bielany site is an exception) located in a given test node. Because CIU triaxial tests were made by using core samples of about $0.4 \mathrm{~m}$ in length, the mean was taken from three, nine, or twelve readings at a given depth and $\pm 0.20 \mathrm{~m}$.

Evaluation of the undrained shear strength $\tau_{f u}$ in preconsolidated cohesive soils from seismic dilatometer tests was performed using single- and multi-factor empirical relationships proposed by: Marchetti (4) [3], Roque et al. (6) [38], and Smith and Houlsby (7) [39], as well as the three-factor relationship of Rabarijoely [41] using Equation (9), the empirical coefficients determined by Lechowicz et al. [48] and the two-factor relationship of Galas [42] using Equation (10).

For each relationship, the maximum relative error max $R E$ (Table 5 ) for the particular test site was selected from the values of relative errors $R E$ calculated according to the formula:

$$
R E=\left|\left(d^{(p)}-y^{(p)}\right) / d^{(p)}\right| \cdot 100 \%
$$

where $p$ is the case number, $p \in\{1, \ldots, P\}, P$ is the number of cases, $d^{(p)}$ is the measured value, and $y^{(p)}$ is the calculated value.

Table 5. The calculated maximum relative error max $R E$ of the evaluated undrained shear strength $\tau_{f u}$ in cohesive soils from the Ursynów, Bielany, and Stegny sites.

\begin{tabular}{|c|c|c|c|c|c|c|}
\hline & & \multicolumn{3}{|c|}{ Single-Factor Relationships by: } & \multicolumn{2}{|c|}{ Multi-Factor Relationship by: } \\
\hline & & $\begin{array}{l}\text { Marchetti [3] } \\
\text { Equation (4) } \\
\max R E \\
(\%)\end{array}$ & $\begin{array}{l}\text { Roque et al. } \\
\text { [38] } \\
\text { Equation (6) } \\
\text { max } R E \\
(\%)\end{array}$ & $\begin{array}{c}\text { Smith and Houlsby } \\
\text { [39] } \\
\text { Equation (7) } \\
\text { max RE } \\
(\%)\end{array}$ & $\begin{array}{c}\text { Rabarijoely [41,51] } \\
\text { Equation (9) } \\
\max R E \\
(\%)\end{array}$ & $\begin{array}{c}\text { Galas [42] } \\
\text { Equation (10) } \\
\max R E \\
(\%)\end{array}$ \\
\hline \multirow{3}{*}{$\begin{array}{l}3 \\
\vdots \\
\vdots \\
5 \\
\vdots \\
5 \\
5\end{array}$} & A & 34.3 & 14.7 & 11.7 & 30.9 & 16.4 \\
\hline & 37 & 36.7 & 30.3 & 21.0 & 47.7 & 21.1 \\
\hline & 34 & 22.8 & 6.0 & 2.8 & 42.5 & 8.6 \\
\hline 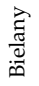 & & 43.9 & 47.6 & 43.2 & 35.9 & 33.9 \\
\hline $\begin{array}{l}\overrightarrow{D_{0}} \\
\vec{\Phi} \\
\vec{\infty}\end{array}$ & & 21.3 & 7.4 & 24.5 & 40.5 & 28.7 \\
\hline \multicolumn{2}{|c|}{$\begin{array}{c}\text { Mean } \\
\max R E\end{array}$} & 31.8 & 21.2 & 20.6 & 39.5 & 21.7 \\
\hline \multicolumn{7}{|c|}{ Mean $R E$ (from 16 tests) } \\
\hline & & 20.4 & 14.1 & 12.0 & 30.6 & 12.9 \\
\hline
\end{tabular}

Using the max $R E$ obtained for five locations the mean value of max $R E$ was calculated for each relationship. Based on all test sites the mean value of the $R E$ was also calculated for a particular relationship (Table 5).

Analysis of the calculation results indicated quite high values of $\max R E$ obtained for the undrained shear strength evaluated on the basis of the single-factor empirical relationship of Marchetti ranging between $21.3-43.9 \%$. The max $R E$ values calculated for $\tau_{f u}$ evaluated from the Roque et al. relationship with the bearing capacity factor $N_{C}$ determined for Pleistocene and Pliocene clays ranged between $6.0-47.6 \%$. The max $R E$ values calculated for undrained shear strength evaluated from the Smith and Houlsby relationship with the bearing capacity factor $N_{D}$ determined for Pleistocene and Pliocene clays were in the range of $2.8-43.2 \%$. The mean values of the max $R E$ for the Marchetti, Roque et al., 
and Smith and Houlsby relationships were 31.8, 21.2, and 20.6\%, respectively. The mean values of the relative error RE (from 16 tests) for the Marchetti, Roque et al., and Smith and Houlsby relationships were $20.4,14.1$, and $12.0 \%$, respectively.

The comparison carried out for the three-factor relationship of Rabarijoely, for which the empirical coefficients were determined for Pleistocene and Pliocene clays, indicated quite high max $R E$ values of the $\tau_{f u}$ in the range of $30.9-47.7 \%$. The mean value of max $R E$ was $39.5 \%$ and the mean values of relative error $R E$ (from 16 tests) was $30.6 \%$. Using the two-factor relationship of Galas, the max $R E$ values of the $\tau_{f u}$ ranged between $8.6-33.9 \%$, the mean value of max $R E$ was $21.7 \%$ with the mean value of relative error equal to $12.9 \%$. This showed that the two-factor relationship of Galas gives a better accuracy compared to the Rabarijoely relationship.

This evidences that the evaluation of the undrained shear strength from dilatometer tests for the Pleistocene and Pliocene clays from the analyzed relationships resulted in quite high max $R E$ values exceeding 34\%. However, in the case of the Roque et al., Smith and Houlsby, and Galas relationships, the mean values of the max RE showed better accuracy and were at about $21 \%$. From among the single-factor empirical relationships the Smith and Houlsby relationship and from among the multi-factor relationships the Galas relationship gave better accuracy with the mean value of the relative error $R E$ at about $12 \%$ and $13 \%$, respectively.

\section{Statistical Analysis}

Statistical analysis of the SDMT results was carried out using the Statistica software version 12 [54-56]. Models of linear and nonlinear regression were analyzed [57]. The analyzed data set comprised the $P=16$ pattern described by one dependent variable the normalized undrained shear strength $Y=\tau_{f u} / \sigma_{v}^{\prime} \in\{0.803-2.382\}$, and four independent variables: The normalized net value of the corrected first pressure reading $X_{1}=\left(p_{o}-u_{0}\right) / \sigma_{v}^{\prime} \in\{4.301-13.743\}$; the normalized net value of the corrected second pressure reading $X_{2}=\left(p_{1}-u_{0}\right) / \sigma_{v}^{\prime} \in\{9.222-27.525\}$; the normalized difference between corrected second pressure reading and the corrected first pressure reading $X_{3}=\left(p_{1}-p_{0}\right) / \sigma_{v}^{\prime} \in$ $\{3.559-13.782\}$; and the normalized shear wave velocity $X_{4}=V_{s} / 100 \in\{1.750-4.240\}$, selected from the variables presented in Table 4.

Simple regression models were considered:

$$
y=a+b x \pm S E E
$$

where $a$ is intercept of line, $b$ is slope of line, and SEE is the standard error of estimation.

In the case when measurement of the shear wave velocity $V_{s}$ was not carried out, the $\tau_{f u} / \sigma_{v}^{\prime}$ can be evaluated using simple linear regressions shown as Equation (13) or Equation (14), which explain $85.5 \%$ and $83.1 \%$ of the variability of $Y=\tau_{f u} / \sigma_{v}^{\prime}$, respectively (Table 6). Plots of regression lines (13) and (14) with 95\% confidence intervals are given in Figure 8. The simple linear regression models (15) and (16) shown in Table 6 gave worse accuracy.

Table 6. Comparison of the analyzed simple linear regression models.

\begin{tabular}{cccccc}
\hline \multirow{2}{*}{ Model } & Equation Formula/No. & $\begin{array}{c}\text { Determination } \\
\text { Coefficient } \\
R^{2}(-)\end{array}$ & SEE (MPa) & Max RE (\%) & Mean RE (\%) \\
\hline \multirow{2}{*}{$\begin{array}{c}\text { Simple linear } \\
\text { regressions }\end{array}$} & $\tau_{f u} / \sigma_{v}^{\prime}=0.3023+0.1442\left(\left(p_{o}-u_{0}\right) / \sigma_{v}^{\prime}\right)(13)^{*}$ & 0.855 & \pm 0.2089 & 41.0 & 12.4 \\
\cline { 2 - 7 } & $\tau_{f u} / \sigma_{v}^{\prime}=0.4513+0.0698\left(\left(p_{1}-u_{0}\right) / \sigma_{v}^{\prime}\right)(14)^{* *}$ & 0.831 & \pm 0.2262 & 37.7 & 13.0 \\
\cline { 2 - 7 } & $\tau_{f u} / \sigma_{v}^{\prime}=0.6652+0.1258\left(\left(p_{1}-p_{o}\right) / \sigma_{v}^{\prime}\right)(15)^{* *}$ & 0.751 & \pm 0.2747 & 39.4 & 15.0 \\
\cline { 2 - 7 } & $\tau_{f u} / \sigma_{v}^{\prime}=-0.1159+0.5178(V s / 100)(16)^{*}$ & 0.757 & \pm 0.2714 & 33.0 & 12.0 \\
\hline
\end{tabular}

Notes: *-coefficient $a$ is statistically non-significant, ${ }^{* *}$-all coefficients are statistically significant. 


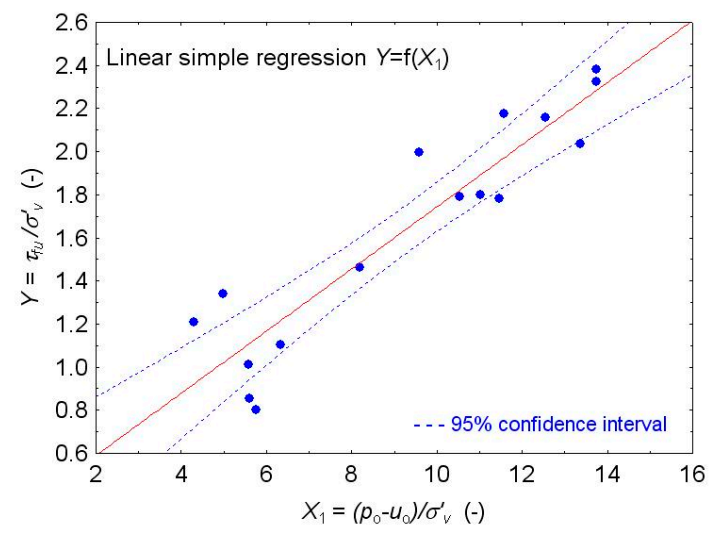

(a)

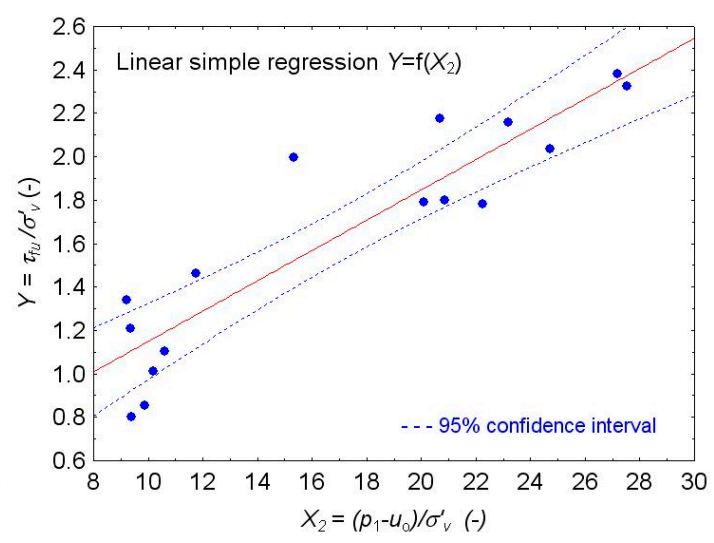

(b)

Figure 8. Linear simple regression models with $95 \%$ confidence intervals: (a) $Y=f(X 1),(\mathbf{b}) Y=f(X 2)$.

The linear two-factor regression model was in the form of:

$$
y=a_{o}+a_{1} x_{1}+a_{2} x_{2} \pm S E E
$$

where $a_{0}, a_{1}$, and $a_{2}$ are regression coefficients.

The non-linear two-factor regression model was adopted based on the analysis of the curve shape and scatterplots of variables. Among the linearized models, i.e., those that can be reduced to a linear form by appropriate transformation of variables or parameters, the power function of the form was selected:

$$
y=\beta_{0} \cdot x_{1} \beta_{1} \cdot x_{2} \beta_{2}
$$

Logarithmic transformation was applied and a transformed regression model was obtained:

$$
\log y=\log \beta_{o}+\beta_{1} \cdot \log x_{1}+\beta_{2} \cdot \log x_{2}
$$

The non-linear two-factor regression was considered as the best model. The fulfilment of statistical assumptions (e.g., normality of residual distribution and residuals analysis) was checked.

A non-linear two-factor relationship to evaluate the normalized undrained shear strength $\tau_{f u} / \sigma_{v}^{\prime}$ of preconsolidated cohesive soils based on seismic dilatometer test in a general form is proposed as follows:

$$
\frac{\tau_{f u}}{\sigma_{v}^{\prime}}=\beta_{o} \cdot\left(\frac{p_{1}-p_{o}}{\sigma_{v}^{\prime}}\right)^{\beta_{1}} \cdot\left(\frac{V s}{100}\right)^{\beta_{2}}
$$

where $\beta_{0}, \beta_{1}$, and $\beta_{2}$ are the empirical coefficients. The empirical coefficients to Equation (20) for Pleistocene clays and Pliocene clays were evaluated by statistical analysis using the input and output data shown in Table 4. The empirical coefficients of the linear two-factor relationship (Equation (21))

\begin{tabular}{|c|c|c|c|c|c|}
\hline Model & Equation Formula/No. & $\begin{array}{l}\text { Determination } \\
\text { Coefficient } \\
R^{2}(-)\end{array}$ & SEE (MPa) & $\operatorname{Max} R E(\%)$ & Mean $R E(\%)$ \\
\hline $\begin{array}{l}\text { Linear multiple } \\
\text { two-factor regression }\end{array}$ & $\begin{aligned} \tau_{f u} / \sigma_{v}^{\prime}= & 0.0403+0.0728\left(\left(p_{1}-p_{o}\right) / \sigma_{v}^{\prime}\right)+ \\
& +0.3055(V s / 100)(21)^{*}\end{aligned}$ & 0.881 & \pm 0.1972 & 19.1 & 8.5 \\
\hline $\begin{array}{l}\text { Non-linear multiple } \\
\text { two-factor regression }\end{array}$ & $\begin{aligned} \tau_{f u} / \sigma_{v}^{\prime}= & 0.3676 \cdot\left(\left(p_{1}-p_{o}\right) / \sigma_{v}^{\prime}\right)^{0.2846} . \\
& (V s / 100)^{0.7525}(22)^{* *}\end{aligned}$ & 0.919 & \pm 0.0480 & 20.4 & 8.5 \\
\hline
\end{tabular}
and non-linear two-factor relationship (Equation (22)) are presented in Table 7. Graphic presentation of the proposed relationship is shown in Figure 9.

Table 7. Comparison of the analyzed two-factor regression models.

Notes: *-coefficient $a$ is statistically non-significant, ${ }^{* *}$-all coefficients are statistically significant. 


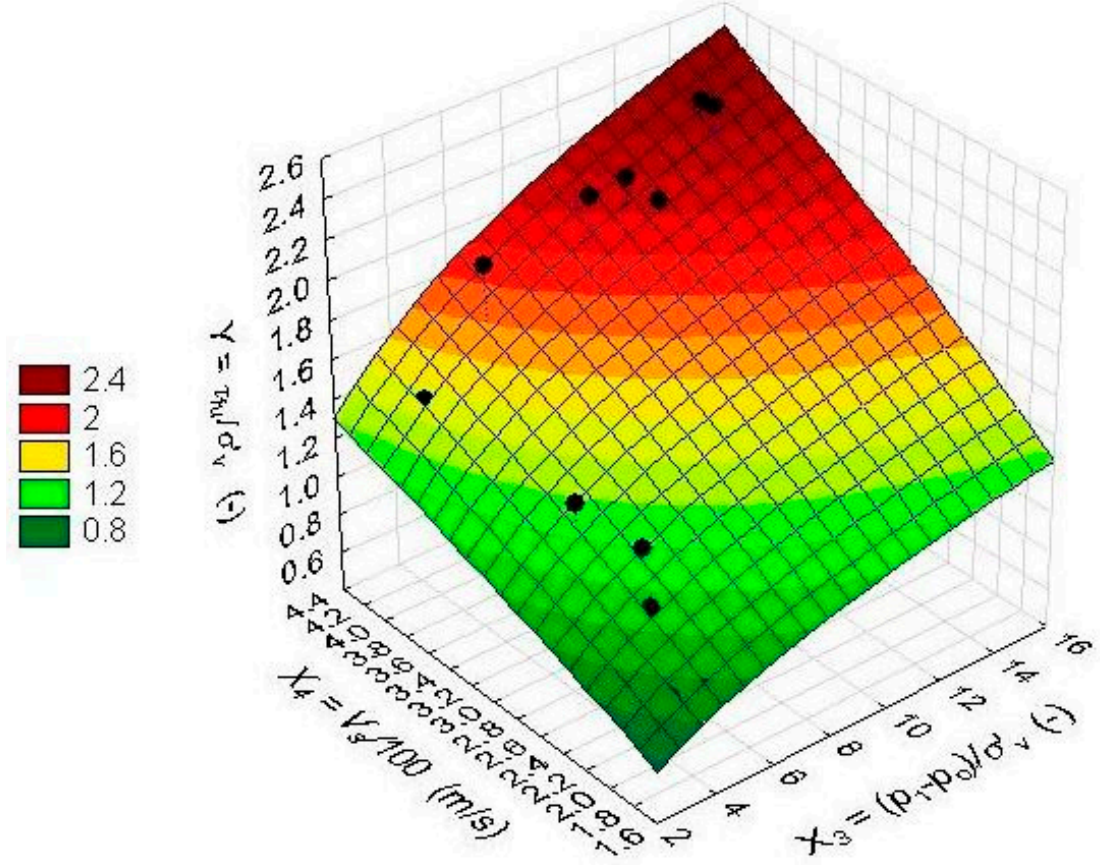

Figure 9. Graphic presentation of the proposed relationship (Equation (22)).

The proposed non-linear two-factor relationship (Equation (22), Table 7) was considered the best of all analyzed relationships. The accuracy of the prediction using the proposed relationship (Equation (22)) is illustrated by a graph of the dependence of the measured $\tau_{f u} / \sigma_{v}^{\prime}$ values and $\tau_{f u} / \sigma_{v}^{\prime}$ values predicted by the proposed relationship (Equation (22), Figure 10). The maximum relative prediction error max $R E$ of the proposed relationship for $\tau_{f u} / \sigma_{v}^{\prime}$ based on all the data was $\pm 20.4 \%$. A comparison between measured values of $\tau_{f u} / \sigma_{v}^{\prime}$ obtained from the CIU triaxial tests and values of $\tau_{f u} / \sigma_{v}^{\prime}$ evaluated using the proposed relationship (Equation (22)) are shown in Table 8. The mean value of the max $R E$ was about $13.2 \%$ and the mean value of the relative error $R E$ for all data was about $8.5 \%$.

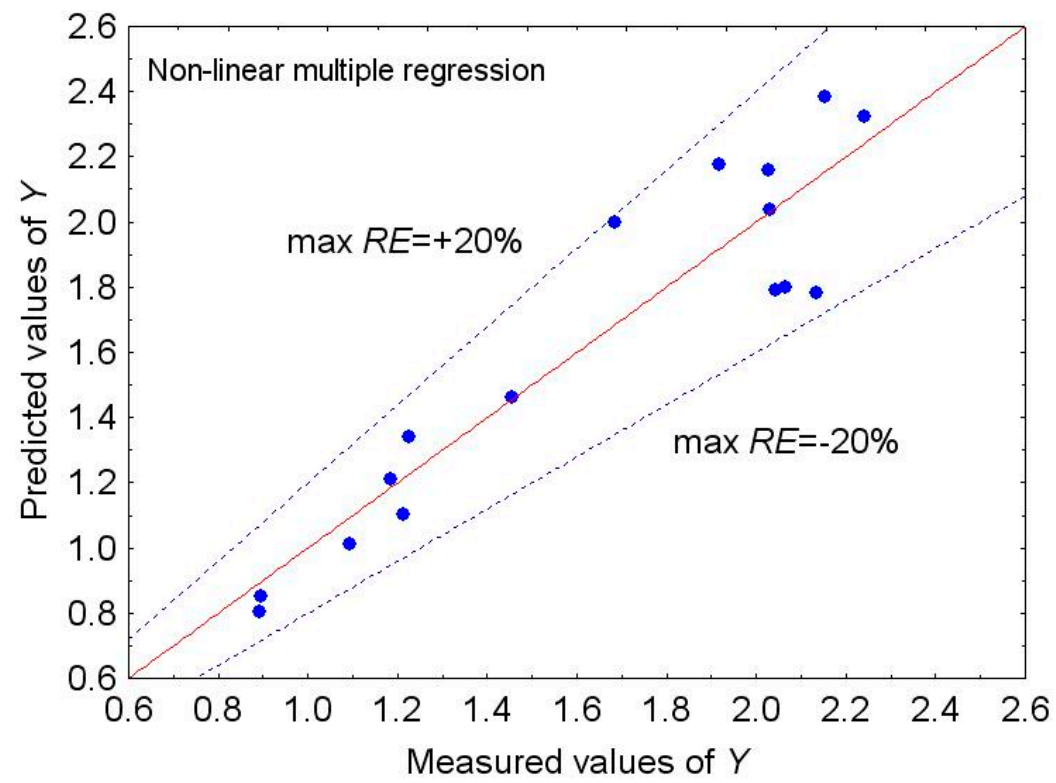

Figure 10. Comparison between measured values of the normalized undrained shear strength $\tau_{f u} / \sigma_{v}^{\prime}$ and values predicted by the proposed relationship (Equation (22)). 
Table 8. Comparison between measured values of $\tau_{f u} / \sigma_{v}^{\prime}$ obtained from the CIU triaxial tests and values of $\tau_{f u} / \sigma_{v}^{\prime}$ predicted using the proposed relationship (Equation (22)). Bold number shows the maximum value of $R E$ for given site

\begin{tabular}{|c|c|c|c|c|}
\hline & Sites & $\begin{array}{l}\text { Measured Values } \tau_{f u} / \sigma_{v}^{\prime} \\
\text { from CIU TT }(-)\end{array}$ & $\begin{array}{c}\text { Predicted Values } \tau_{f u} / \sigma_{v}^{\prime} \text { Using } \\
\text { Equation (22) (-) }\end{array}$ & $\begin{array}{l}\text { Relative Errors of Individual } \\
\text { Case } R E_{p}(\%)\end{array}$ \\
\hline \multirow{9}{*}{ 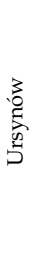 } & \multirow{3}{*}{ A } & 2.382 & 2.134 & 10.4 \\
\hline & & 2.323 & 2.228 & 4.1 \\
\hline & & 1.780 & 2.143 & 20.4 \\
\hline & \multirow{3}{*}{37} & 2.038 & 2.018 & 1.0 \\
\hline & & 2.176 & 1.918 & 11.9 \\
\hline & & 1.997 & 1.706 & 14.6 \\
\hline & \multirow{3}{*}{34} & 1.800 & 2.076 & 15.3 \\
\hline & & 1.789 & 2.056 & 14.9 \\
\hline & & 2.158 & 2.023 & 6.2 \\
\hline \multirow{4}{*}{$\frac{\vec{d}}{\stackrel{\vec{d}}{0}}$} & & 1.463 & 1.490 & 1.9 \\
\hline & & 1.209 & 1.149 & 4.9 \\
\hline & & 1.342 & 1.210 & 9.8 \\
\hline & & 1.103 & 1.196 & 8.5 \\
\hline \multirow{6}{*}{$\begin{array}{l}\overrightarrow{\Phi_{0}} \\
\text { के }\end{array}$} & & 0.853 & 0.847 & 0.8 \\
\hline & & 0.803 & 0.851 & 6.0 \\
\hline & & 1.011 & 1.059 & 4.7 \\
\hline & & & & $\operatorname{Max} R E_{p}=20.4 \%$ \\
\hline & & & The mean of the marked values & Mean Value of Max $R E=13.2 \%$ \\
\hline & & & & Mean Value of $R E=8.5 \%$ \\
\hline
\end{tabular}

\section{Conclusions}

The analysis carried out for Pleistocene and Pliocene clays indicates that the evaluated undrained shear strength $\tau_{f u}$ from the dilatometer test on the basis of single-factor empirical relationships: Marchetti, Roque et al., and Smith and Houlsby gives quite high values of the maximum relative error max RE from $43 \%$ up to $48 \%$. The two-factor relationship of Galas presented somewhat smaller values of the max $R E$ up to $34 \%$. From the single-factor empirical relationships the Smith and Houlsby relationship and from the multi-factor relationships the Galas relationship gave better accuracy with the mean value of relative error $R E$ at about $12 \%$ and $13 \%$, respectively. So far the shear wave velocity $V_{s}$ as an independent variable was not used to evaluate the undrained shear strength from the dilatometer test.

The normalized undrained shear strength $\tau_{f u} / \sigma_{v}^{\prime}$ in Pleistocene and Pliocene clays from the seismic dilatometer test (SDMT) can be evaluated using the proposed two-factor relationship based on the normalized difference between the corrected second pressure reading and the corrected first pressure reading $\left(p_{1}-p_{o}\right) / \sigma_{v}^{\prime}$, and the normalized shear wave velocity $V_{s} / 100$. The proposed relationship provides the evaluation of the normalized undrained shear strength $\tau_{f u} / \sigma_{v}^{\prime}$ in Pleistocene and Pliocene clays from the seismic dilatometer test with a maximum relative error at about $\pm 20 \%$ and with the mean value of relative error $R E$ at about $8 \%$. Further research is needed for different types of cohesive soils with a higher variability of the plasticity index $I_{P}$, consistency index $I_{C}$, and stress history to verify empirical coefficients determined in this study.

Author Contributions: P.G. prepared the research program, performed the SDMT tests, analyzed the test results, and prepared the manuscript. Z.L. prepared the research program, analyzed the test results and prepared the manuscript. M.J.S. performed the statistical analysis and prepared the manuscript.

Funding: This research was funded by the Polish Ministry of Science and Higher Education.

Acknowledgments: This work was carried out in cooperation with the partners from the Warsaw University of Life Sciences, Warsaw, Poland and the Bialystok University of Technology, Bialystok, Poland and was supported by the Polish Ministry of Science and Higher Education. A seismic dilatometer was used in the research purchased as part of the project "Water Center" of the Faculty of Civil and Environmental Engineering at the Warsaw University of Life Sciences implemented under the Operational Program Infrastructure and Environment, Measure 13.1, priority XII in 2010.

Conflicts of Interest: The authors declare no conflict of interest. 


\section{References}

1. Mayne, P.W.; Coop, M.R.; Springman, S.M.; Huang, A.B.; Zornberg, J.G. Geomaterial behaviour and testing. State of the Art (SOA) paper. In Proceedings of the 17th International Conference on Soil Mechanics and Geotechnical Engineering, Alexandria, Egypt, 18-21 October 2009; Volume IV, pp. 2777-2872.

2. Robertson, P.K. The James K. Mitchell Lecture: Interpretation of in-situ tests-Some insights. In Proceedings of the Fourth International Conference on Geotechnical and Geophysical Site Characterization, Porto de Galinhas, Brazil, 18-21 September 2012; Volume I, pp. 3-24.

3. Marchetti, S. A new in situ test for the measurement of horizontal soil deformability. In Proceedings of the Conference on In Situ Measurement of Soil Properties, ASCE, Raleigh, NC, USA, 1-4 June 1975; Volume 2, pp. 255-259.

4. Marchetti, S. In Situ Tests by Flat Dilatometer. J. Geotech. Geoenviron. Eng. 1980, 106, $299-321$.

5. Marchetti, S. Some 2015 Updates to the TC16 DMT Report 2001. In Proceedings of the 3rd International Conference on the Flat Dilatometer (DMT'15), Roma, Italy, 14-16 June 2015; pp. 43-65.

6. Marchetti, S. Flat dilatometer (DMT). Applications and recent developments. In Proceedings of the Indian Geotechnical Conference, Pune, India, 16-19 December 2015.

7. Marchetti, S.; Monaco, P.; Totani, G.; Calabrese, M. The flat dilatometer test (DMT) in soil investigations-A report by the ISSMGE Committee TC16. In Proceedings of the International Conference on Insitu Measurement of Soil Properties and Case Histories, Bali, Indonesia, 21-24 May 2001; p. 41.

8. Marchetti, S.; Crapps, D.K. Flat Dilatometer Manual; Internal Report of GPE; GPE: Princeton, NJ, USA, 1981.

9. Lutenegger, A.J. Current status of the Marchetti dilatometer test. In Proceedings of the 1st International Symposium on Penetration Testing (ISOPT-1), Orlando, FL, USA, 20-24 March 1988; Volume 1, pp. $137-155$.

10. Briaud, J.L.; Miran, J. The Flat Dilatometer Test; Publ. FHWA-SA-91-044; Civil Engineering Department, Texas A\&M, for Federal Highway Administration: College Station, TX, USA, 1991.

11. Ozer, A.T;; Bartlett, S.F.; Lawton, E.C. DMT testing for consolidation properties of the Lake Bonneville Clay. In Proceedings of the 2nd International Flat Dilatometer Conference, Washington, DC, USA, 2-5 April 2006; pp. 154-161.

12. Schnaid, F. In Situ Testing in Geomechanics_The Main Tests; Taylor \& Francis Group: London, UK, 2009 ; p. 327.

13. Lechowicz, Z.; Rabarijoely, S.; Galas, P.; Kiziewicz, D. Settlement evaluation of spread foundations on heavily preconsolidated cohesive soils. Ann. Warsaw Univ. Life Sci. SGGW Land Reclam. 2011, 43, 111-118. [CrossRef]

14. Robertson, P.K. Soil behavior type using the DMT. In Proceedings of the 3rd International Flat Dilatometer Conference, Roma, Italy, 14-16 June 2015; pp. 243-250.

15. Cao, L.; Chang, M.F.; Teh, C.I. Analysis of dilatometer test in clay. In Proceedings of the 3rd International Conference on the Flat Dilatometer (DMT'15), Roma, Italy, 14-16 June 2015; pp. 385-392.

16. Młynarek, Z.; Wierzbicki, J.; Lunne, T. On the influence of overconsolidation effect on the compressibility assessment of subsoil by means of CPTU and DMT. Ann. Warsaw Univ. Life Sci. SGGW Land Reclam. 2016, 48, 189-200. [CrossRef]

17. Schnaid, F.; Odebrecht, E.; Sosnoski, J.; Robertson, P.K. Effects of the procedure on flat dilatometer test (DMT) results in intermediate soils. Can. Geotech. J. 2016, 53, 1270-1280. [CrossRef]

18. Marchetti, S.; Monaco, P.; Totani, G.; Marchetti, D. In situ tests by Seismic Dilatometer (SDMT). In From Research to Practice in Geotechnical Engineering, Proceedings of the GeoCongress 2008, New Orleans, LA, USA, 9-12 March 2008; ASCE Library: Reston, VA, USA, 2008; pp. 292-311.

19. Marchetti, S. The seismic dilatometer for in situ soil investigations. In Proceedings of the Indian Geotechnical Conference IGC-2014, Kakinada, India, 18-20 December 2014; pp. 1-9.

20. Martin, G.K.; Mayne, P.W. Seismic Flat Dilatometer tests in Connecticut Valley varved clay. ASTM Geotech. Testing J. 1997, 20, 357-361. [CrossRef]

21. Martin, G.K.; Mayne, P.W. Seismic Flat Dilatometer in Piedmont residual soils. In Proceedings of the 1st International Conference on Site Characterization, Atlanta, GA, USA, 19-22 April 1998; Robertson, P.K., Mayne, P.W., Eds.; 1998; Volume 2, pp. 837-843.

22. Cavallaro, A.; Grasso, S.; Maugeri, M. Clay soil characterization by the New Seismic Dilatometer Marchetti Test (SDMT). In Proceedings of the Second International Flat Dilatometer Conference, Washington, DC, USA, 2-5 April 2006; pp. 261-268.

23. Cavallaro, A.; Ferraro, A.; Grasso, S.; Maugeri, M. Site Response Analysis of the Monte Po Hill in the City of Catania. In Proceedings of the 2008 Seismic Engineering International Conference Commemorating the 1908 Messina and Reggio Calabria Earthquake MERCEA'08, Reggio Calabria and Messina, Italy, 8-11 July 2008; pp. 240-251. 
24. Carroll, R.; Long, M.; Ward, D. Use of CPTU and SDMT to characterise silty soil. In Proceedings of the Fourth International Conference on Geotechnical and Geophysical Site Characterization, Porto de Galinhas, Brazil, 18-21 September 2012; Volume I, pp. 214-249.

25. Rivera-Cruz, I.; Howie, J.; Vargas-Herrera, L.A.; Coto-Loria, M.; Luna-Gonzales, O. A new approach for identification of soil behaviour type from seismic dilatometer (SDMT) data. In Proceedings of the Fourth International Conference on Geotechnical and Geophysical Site Characterization, Porto de Galinhas, Brazil, 18-21 September 2012; Volume II, pp. 947-954.

26. Totani, G.; Monaco, P.; Marchetti, S.; Marchetti, D. Vs measurements by seismic dilatometer (SDMT) in non-penetrable soils. In Proceedings of the 17th International Conference on Soil Mechanics and Geotechnical Engineering, Alexandria, Egypt, 18-21 October 2009; Volume II, pp. 977-980.

27. Monaco, P.; Marchetti, S.; Totani, G.; Marchetti, D. Interrelationship between small strain modulus Go and operative modulus. In Proceedings of the International Conference on Performance-Based Design in Earthquake Geotechnical Engineering (IS-Tokyo 2009), Tsukuba, Japan, 15-17 June 2009; Tsukamoto, K., Yoshimine, Eds.; 2009; pp. 1315-1323.

28. Młynarek, Z.; Wierzbicki, J.; Stefaniak, K. Deformation characteristics of overconsolidated subsoil from CPTU and SDMT tests. In Proceedings of the Fourth International Conference on Geotechnical and Geophysical Site Characterization, Porto de Galinhas, Brazil, 18-21 September 2012; Volume II, pp. 1189-1193.

29. Amoroso, S.; Monaco, P.; Marchetti, D. Use of the Seismic Dilatometer (SDMT) to estimate in situ G- $\gamma$ decay curves in various soil types. In Proceedings of the Fourth International Conference on Geotechnical and Geophysical Site Characterization, Porto de Galinhas, Brazil, 18-21 September 2012; Volume I, pp. 489-497.

30. Vargas, L.A.; Coto, M. Experiences in the use of DMT-SDMT in Costa Rica, Central America. In Proceedings of the Fourth International Conference on Geotechnical and Geophysical Site Characterization, Porto de Galinhas, Brazil, 18-21 September 2012; Volume I, pp. 375-382.

31. Cavallaro, A.; Capilleri, P.; Grasso, S. Site Characterization by in Situ and Laboratory Tests for Liquefaction Potential Evaluation during Emilia Romagna Earthquake. Geosciences 2018, 8, 242. [CrossRef]

32. Arroyo, M.; Di Mariano, A.; Monaco, P.; Devincenzi, M.; Perez, N. SDMT—based deep excavation design. In Proceedings of the Third International Conference on Geotechnical and Geophysical Site Characterization, Taipei, Taiwan, 1-4 April 2008; pp. 967-973.

33. Młynarek, Z.; Gogolik, S.; Gryczmański, M.; Ulniarz, R. Settlement analysis of a cylindrical tank based on CPTU and SDMT results. In Proceedings of the Fourth International Conference on Geotechnical and Geophysical Site Characterization, Porto de Galinhas, Brazil, 18-21 September 2012; Volume II, pp. 1585-1590.

34. Kulhawy, F.H.; Mayne, P.W. Manual on Estimating Soil Properties for Foundation Design; Report EK-6800; Electric Power Research Institute: Palo Alto, CA, USA, 1990.

35. Burland, J.B. On the compressibility and shear strength of natural soils. Géotechnique 1990, 40, 329-378. [CrossRef]

36. Houlsby, N.M.T.; Houlsby, G.T. Statistical fitting of undrained strength data. Géotechnique 2013, 63, 1253-1263. [CrossRef]

37. Ching, J.; Phoon, K.-K. Multivariate distribution for undrained shear strengths under various test procedures. Can. Geotech. J. 2013, 50, 907-923. [CrossRef]

38. Roque, R.; Janbu, N.; Senneset, K. Basic interpretation procedures of flat dilatometer tests. In Proceedings of the 1st International Symposium on Penetration Testing, Orlando, FL, USA, 20-24 March 1988; Volume 1, pp. 577-587.

39. Smith, M.G.; Houlsby, G.T. Interpretation of the Marchetti Dilatometer in Clay. In Proceedings of the 11th European Conference on Soil Mechanics and Foundation Engineering, Kopenhaga, Denmark, 28 May-1 June 1995; Volume 1, pp. 1.247-1.253.

40. Iwasaki, K.; Kamei, I. Evaluation of in situ strength and deformation characteristics of soils using a Flat Dilatometer. J. Geotech. Eng. 1994, 499, 167-176.

41. Rabarijoely, S. The Use of Dilatometer Test for Evaluation of Organic Soil Parameters. Ph.D. Thesis, Warsaw Agricultural University-SGGW, Land Reclamation, Warszawa, Poland, 2000. (In Polish).

42. Galas, P. Determination of Undrained Shear Strength Based on Seismic Dilatometer Test SDMT. Ph.D. Thesis, Warsaw University of Life Sciences-SGGW, Warsaw, Poland, 2013. (In Polish).

43. Yu, H.S.; Carter, J.P.; Booker, J.R. Analysis of the dilatometer test in undrained clay. In Predictive Soil Mechanics, Proceedings of the Wroth Memorial Symposium, Oxford, UK, 27-29 July 1993; ICE Virtual Library: London, UK, 1993; pp. 783-795. 
44. Kamei, I.; Iwasaki, K. Evaluation of undrained shear strength of cohesive soils using a flat dilatometer. Soils Found. 1995, 35, 111-116. [CrossRef]

45. Lutenegger, A.J. Cavity expansion model to estimate undrained shear strength in soft clay from dilatometer. In Proceedings of the Second International Flat Dilatometer Conference, Washington, DC, USA, 2-5 April 2006; pp. 319-326.

46. Hong, S.J.; Shin, D.H.; Yoon, H.K.; Lee, C.; Lee, W.; Kim, Y.U. Strength and modulus of Busan clay by DMT. In Proceedings of the Third International Conference on Geotechnical and Geophysical Site Characterization, Taipei, Taiwan, 1-4 April 2008; pp. 377-382.

47. Silvestri, V.; Tabib, C. Application of the MCC model for the estimation of undrained geotechnical parameters of clays from dilatometer tests. In Proceedings of the 3rd International Conference on the Flat Dilatometer (DMT'15), Roma, Italy, 14-16 June 2015; pp. 431-438.

48. Lechowicz, Z.; Fukue, M.; Rabarijoely, S.; Sulewska, M.J. Evaluation of the undrained shear strength of organic soils from a dilatometer test using artificial neural networks. Appl. Sci. 2018, 8, 1395. [CrossRef]

49. ISO 22476-11:2017 Geotechnical Investigation and Testing-Field Testing-Part 11: Flat Dilatometer Test; International Organization for Standardization: Geneva, Switzerland, 2017.

50. ASTM D6635-15 Standard Test Method for Performing the Flat Plate Dilatometer; ASTM International: West Conshohocken, PA, USA, 2015.

51. Lechowicz, Z.; Rabarijoely, S.; Kutia, T. Determination of undrained shear strength and constrained modulus from DMT for stiff overconsolidated clays. Ann. Warsaw Univ. Life Sci. SGGW Land Reclam. 2017, 49, 107-116. [CrossRef]

52. EN ISO 14688-1:2002. Geotechnical Investigation and Testing-Identification and Classification of Soil—Part 1: Identification and Description; International Organization for Standardization: Geneva, Switzerland, 2002.

53. EN ISO 14688-2:2004. Geotechnical Investigation and Testing-Identification and Classification of Soil-Part 2: Principles for a Classification; International Organization for Standardization: Geneva, Switzerland, 2004.

54. STATISTICA—Package Documentation; StatSoft Polska Ltd.: Cracow, Poland, 2002. (In Polish)

55. Stanisz, A. Accessible Statistics Course Using STATISTICA PL on the Examples of Medicine; StatSoft Polska Ltd.: Cracow, Poland, 2006; Volume 1. (In Polish)

56. Stanisz, A. Accessible Statistics Course Using STATISTICA PL on the Examples of Medicine; StatSoft Polska Ltd.: Cracow, Poland, 2007; Volume 3. (In Polish)

57. Draper, N.R.; Smith, H. Applied Regression Analysis, 3rd ed.; Wiley: New York, NY, USA, 1998. 